\title{
PROTECTIVE MECHANICAL VENTILATION IN PATIENTS WITHOUT OR WITH LUNG INJURY
}

\author{
Sutherasan Yuda, ${ }^{1,2}$ Vargas Maria, ${ }^{3}$ Rodríguez-González Raquel, ${ }^{4,5}$ Pelosi Paolo ${ }^{1}$ \\ ${ }^{1}$ Department of Surgical Sciences and Integrated Diagnostics, University of Genoa, \\ IRCCS San Martino - IST, Genoa, Italy \\ ${ }^{2}$ Ramathibodi Hospital, Mahidol University, Bangkok, Thailand \\ ${ }^{3}$ Department of Neuroscience and Reproductive and Odontostomatological Sciences, \\ University of Naples "Federico II", Italy \\ ${ }^{4}$ Multidisciplinary Organ Dysfunction Evaluation Research Network, Research Unit, \\ Hospital Universitario Dr. Negrín, Las Palmas de Gran Canaria, Spain \\ ${ }^{5}$ Critical Patient Translational Research Group, Department of Anesthesiology, \\ Intensive Care and Pain Management, Hospital Clínico Universitario, Instituto de Investigación Sanitaria (IDIS), \\ University of Santiago de Compostela, Santiago de Compostela, Spain
}

Abstract: The mortality of Acute Respiratory Distress Syndrome (ARDS) is still high from 27 to $45 \%$ according to Berlin definition. Even in surgical patients without lung injury, the postoperative pulmonary complications (PPCs) are frequent. Mechanisms of ARDS, ventilator associated lung injury (VALI) and PPCs are better understood. In ARDS, protective ventilation with low tidal volume $6 \mathrm{ml} / \mathrm{kg}$ PBW and higher levels of positive end-expiratory pressure (PEEP) is widely accepted as routine practice. In no ARDS patients undergoing mechanical ventilation, protective ventilation with low tidal volume $6 \mathrm{ml} / \mathrm{kg}$ PBW and low to moderate levels of PEEP has become the new challenge paradigm shift of supportive care mainly in ICU and perioperative patients. Respiratory monitoring is very helpful for optimizing mechanical ventilator setting to prevent VALI and early detect PPCs during the perioperative period. Several scores have been developed to stratify the risk of ARDS, VALI and PPCs. It's time to apply basic physiologic knowledge of respiratory function and evidence based practice to improve ARDS and PPCs outcomes.

Key words: Ventilator-Associated Lung Injury, Acute Respiratory Distress Syndrome, Transpulmonary pressure, Positive End Expiratory Pressure, Protective ventilation, Respiratory monitoring.

\section{INTRODUCTION}

Using the original American-European Consensus Conference (AECC) definition of the Acute Respi- ratory Distress Syndrome (ARDS), the incidence of ARDS was vary from 5-33.8 cases per 100,000 populations (1). Several studies have shown the improvement of outcome in selected groups of ARDS and the ARDS related mortality was gradually decreased from $70 \%$ to $40 \%$ in the last decades.

According to the limitations of AECC definition of ARDS i.e. the decrease in usage of Swan-Ganz catheter to distinguish the presence of hydrostatic edema and poor sensitivity of $\mathrm{PaO} 2 / \mathrm{FiO} 2$ ratio in different levels of positive end expiratory pressure (PEEP), the Berlin definition has been developed in order to yield better predictability for mortality than AECC definition, to be easily for clinical research implementation as well as to exclude the term acute lung injury for avoiding possible misinterpretation (2). Recent studies have demonstrated that various severities of ARDS according to Berlin definition are associated with the degree extravascular lung water index, pulmonary vascular permeability index by using transpulmonary thermodilution method (3) and the finding of diffuse alveolar damage at autopsy $(4,5)$. The mortality of ARDS is still high from mild to severe as 27 to $45 \%$ by Berlin definition (2).

Not only ARDS but also pulmonary complications particularly during perioperative period and in intensive care unit (ICU) with previously non-injured lung became an interesting issue. A recent, large European cohort study involving 46,539 patients who un- 
derwent non-cardiac surgery have shown unpredictably high mortality as 4\% (6) which may resulted from the high incidence of postoperative pulmonary complications (PPCs) (7). The incidence of PPCs varies according to the definitions of each study. PPCs were classified as respiratory failure from pulmonary or cardiac origin, pneumonia, respiratory infection, pleural effusion, atelectasis, pneumothorax, bronchospasm, need of non-invasive respiratory support and re-intubation as well as mortality. These complications are associated with underlying status, types of surgery or anaesthesia as well as the mechanical ventilator settings (7).

Several studies have shown that mechanical ventilation (MV) not only preserves the life but can aggravate ventilator associated lung injury (VALI). Recent studies have focused on the new strategies for treatment and prevention of ARDS and VALI $(8,9,10)$.

In ARDS, protective ventilation is now widely accepted as the routine practice. In non-ARDS patients with $\mathrm{MV}$, protective ventilation has become the new challenge paradigm shift of supportive care mainly in ICU and perioperative patients as well as heart beating organ donors (11). In this article, we aim to describe: 1) the pathophysiology of ventilator associated lung injury in ARDS and the PPCs in non ARDS patients; 2) the bedside respiratory monitoring tools; 3 ) the recent evidence of protective ventilator strategies in both ARDS and non ARDS patients as well as adjunctive therapies; and 4) the predictive scores of ARDS, VALI and postoperative pulmonary complications.

\section{Mechanisms of ventilator associated lung injury and postoperative pulmonary complications}

\subsection{Atelectrauma, volume trauma, barotrauma}

Ventilation at high lung volume has been shown yielding to alveolar rupture and barotrauma. Several experimental studies have demonstrated that the high MV pressure setting induces rupture of air space not from the absolute pressure itself, but from the degree of lung over distension. Thus, the end inspiratory plateau and tidal volume (VT) per ideal body weight are inadequate parameters to determine the real lung stress and strain. The major determinants of VALI are lung stress or distending force (depend on the applied transpulmonary pressure [PL]) greater than 20-24 cm H2O during inspiration and lung strain defined by the proportion of applied tidal volume plus inflated lung volume due to PEEP application and the resting lung volume (functional residual capacity) greater than $1.5-2(12,13)$. Even in healthy lung, experimental study suggested that long term high tidal volume ventilation with lung strain of 2.5 caused the animals died from respiratory failure (14). If the lungs are inhomogeneous, the applied force will mainly stress on the regions around collapsed and consolidated part which joining to those of opened part. This leads to the increase in stress and strain at wall of opening alveoli particularly in higher alveolar volume (pressure multipliers or lung stress raiser) (12). Lung inhomogeneity is associated with overall mortality and severity of ARDS (12).

During ventilation at low lung volume, repetitive tidal-cyclic opening and closing of alveoli and distal airway leads to shear stress so called atelectrauma. The surfactant dysfunction results in airway collapse hence atelectrauma by the force that generated by surface tension and consequence to an increase of stress and strain. The maneuver which aiming to decrease the lung inhomogeneity such as higher PEEP improved oxygenation and tended to decrease in mortality (15).

In addition to mechanisms associated with VALI, others mechanisms producing PPCs are: 1) general anesthesia, sedation and muscle paralysis caused a reduction of respiratory muscle tone, oxygen reabsorption lead to an increase in atelectasis as well as peripheral airway closure; 2) reduction of functional residual capacity; 3) altering of diaphragmatic position (cephalic shift of diaphragm); 4) redistribution of thoracic blood volume and 6) surfactant inactivation.

\subsection{Biotrauma}

Lung cells have mechanisms that allow them to deal with physiological deformations during normal breathing. Nevertheless, under mechanical ventilation, such forces might be excessive and lead to cell injury. The concept of biotrauma arised in the early 1990s, when several experiments revealed the existence of a relevant biological response to mechanical forces (16, 17). Biotrauma involves the local release of inflammatory mediators that reach the systemic circulation spreading the damage, an excessive activation of the immune system, as well as other numerous cellular responses triggered by mechanical forces (18). The numerous effects of these multiple biological responses greatly account for the high mortality of patients with lung injury and ARDS from multiple organ dysfunction syndrome (19).

\subsubsection{Effects on alveolar epithelium, endothelium and extracellular matrix}

The force derived from mechanical ventilation and over inflation involve a rearrangement of the cellular shape of alveolar cells, types I or II, and endothelium. In this context, cytoskeleton plays a crucial role, 
since it provides a physical basis for translating mechanical forces into biochemical responses (mechanotransduction). Cytoskeletal reorganization, integrins and ion channels are major players of this process, activating a complex network of intracellular pathways that eventually result in extracellular matrix remodelling, recruitment of white cells, and cytokine release $(18,20)$. If stress and strain reach the limit of rupture of the fibre system, mechanical failure may occur with direct rupture of alveolar walls and pulmonary capillaries (19).

Toll-like receptors (TLRs) are innate immune sensors expressed by a range of immune cells, and also by epithelial cells (21). TLRs activate the transcription factor nuclear factor kappa B (NF-kappaB), which eventually results in an increased expression of inflammatory genes. The activation of NF-kappaB, which has been established in VALI (22), induces the production of inflammatory mediators like tumor necrosis factor (TNF) alpha, interleukins (IL) 6, IL-8 or IL-1â (19), which, among others, have shown to be importantly involved in the pathophysiology of VALI $(23,24)$. Importantly, cytokines and chemokines released by epithelial cells and alveolar macrophages induce the recruitment of neutrophils to the lung via IL-8 (19), which amplify tissue inflammation.

Molecules that constitute the extracellular matrix (ECM), such as hyaluronan, biglycan, versican, heparan sulfate, fibronectin ortenascin-C are important activators of TLRs $(25,26)$. These molecules have essential functions in many lung pathophysiological processes, as they regulate tissue hydration, macromolecular structure and function, response to inflammatory agents, and tissue repair (27). Current evidence shows that mechanical ventilation, not only at injurious but also at physiologic tidal volume, may deeply affect ECM structure and function $(28,29)$. In this context, ECM modifications may influence the altered mechanical behavior of the lung parenchyma and also contribute to the subsequent inflammatory events, since ECM constituents are among TLR endogenous ligands (27).

Oxidative stress is another important mechanism during biotrauma. Evidence from animal models suggests that oxidative stress and redox imbalance contribute to enhance/perpetuate susceptibility to VALI (30, 31). Lung alveolar and epithelial cells have showed an increase on reactive oxygen species production in response to elevated stretch (32). Elevated oxidant release in serum as well as decreased lung glutathione, the major antioxidant in the lung, were observed in rats ventilated at high tidal volume $(20 \mathrm{~mL} / \mathrm{kg})(33)$. An increased superoxide production has been observed in ventilated patients (34) and, importantly, antioxidant strategies have shown beneficial effects in experimental models both at the local and systemic levels, attenu- ating VALI-associated inflammation, apoptosis and oxidative responses $(35,36)$.

Mechanisms of inflammation, ECM disruption or oxidative stress are, to a greater or lesser extent, eventually associated with cell death. VALI has been shown to induce apoptosis of airway epithelial cells (37). Interestingly, experimental studies showed that hydrogen inhalation as a therapeutic approach provided cytoprotective effects against apoptotic and inflammatory signaling pathway activation during VALI $(36,38)$.

\subsubsection{Mechanisms of repair}

Membrane disruption acts as a mechanotransducer, whereby the influx of calcium after membrane injury leads to the up regulation of mediators as and NF-kappaB. Deformation-induced plasma membrane disruptions have been directly linked to the activation of pro-inflammatory signaling cascades including early stress response genes, chemokine receptors, and adhesion molecules regulation. Plasma membrane homeostasis is a dynamic process, and deformation-induced lipid trafficking is an important cytoprotective mechanism employed by the cell in the face of externally imposed shape change. The balance of these pathways may be influenced by certain conditions that shift the equilibrium towards the favoring of either a pro-injury or pro-repair state (39).

Processes of re-epithelization and collagen degradation are essential in lung repair, and inflammatory cells can modulate both ECM degradation and epithelial cell migration through different mechanisms (40): release of proteases that cleave collagen, gelatin, and elastin; modulation of inflammation toward an anti-inflammatory response; and by directly releasing growth factors that stimulate epithelial cell migration and proliferation (41). González-López et al. have demonstrated that some of these phenomena take place during the repair phase after VALI, concluding that an adequate inflammatory response and ECM remodeling are essential for recovery (42). However, ECM degradation and remodeling are complex mechanisms. If inflammation of pro-fibrotic responses are exaggerated and unbalanced, the process can lead to fibrosis and organ failure (43).

Apart from repair focused on inflammation or ECM, new approaches are emerging. In this sense, several studies have shown promising results using mesenchymal stem cells, which have shown beneficial results, reducing VALI in animal models $(44,45,46)$.

\subsubsection{Biomarkers for VALI}

The majority of biological markers identified in plasma, serum, pulmonary edema fluid, and bronchoal- 
veolar fluid in experimental studies are cytokines and chemokines. None of them distinguishes VALI from other etiologies of lung injury. However, the temporal association between changes in levels of these proteins and changes in tidal volume or PEEP suggests a causative role (47).

The study of a panel of biomarkers has shown superior performance to single biomarkers. Abnormal levels of five biomarkers in plasma provided excellent discrimination for diagnosis of ARDS in patients with severe sepsis, being three of them generated by lung epithelium (48). Interestingly, a recent study has found that VALI is characterized by a particular metabolic profile that suggests alterations in energy and membrane lipids (49).

Although the definition of ARDS is based on clinical criteria, altered levels of plasma biomarkers may be useful to assist in confirming the diagnosis in certain cases, to categorize them, to facilitate selection for clinical trials as well as a valuable tool for identifying patients at risk, determining prognosis and understanding pathogenesis (47).

\section{Respiratory monitoring}

\subsection{Respiratory mechanics and Esophageal pressure measurement}

Generally we can monitor patients receiving MV by observing static airway pressure, measuring respiratory system compliance and analyzing dynamic pressure-volume curve. Terragni et al assessed the accuracy of plateau pressure and stress index to identify the point associated with injurious ventilation. This study demonstrated that plateau pressure (Pplat) more than $25 \mathrm{~cm} \mathrm{H}_{2} \mathrm{O}$ and stress index more than 1.05 have been shown the best performance to define the injurious ventilation (50). In terms of lung strain, the reference value computed by the ventilator is still controversial. Furthermore, the reference volume at Functional residual capacity (FRC) is the lung volume at zero PEEP level and should be at resting lung (pre-stressed condition) (12). Some studies have proposed the reference volume should be the end expiratory lung volume during PEEP application, which considered as continuous strain (12).

The proportion of airway pressure is contributed by the elastance of chest wall. Some conditions that increase chest wall elastance i.e. obesity, abdominal surgery, intra-abdominal hypertension, pleural effusion or even ARDS (H1N1 associated ARDS) make the airway pressure not representing the real stress and strain of the lungs $(51,52)$. MV setting guided by transpulmonary pressure, not airway pressure, and intraabdo- minal pressure monitoring can promote appropriate alveolar recruitment and avoid lung hyperinflation and may prevent further pulmonary complications. In spontaneous breathing patients, during postoperative period, beside pulse oximetry (53) and capnography, esophageal pressure (Peso) can be used to monitor sedative drugs usage, patients-ventilator asynchrony and intrinsic PEEP during weaning from MV in high risk PPCs patients, i.e. COPD patients $(52,54)$.

Talmor et al. have demonstrated the value of Peso guiding for appropriate PEEP levels in ARDS patients to achieve better oxygenation at 72 hours compared with MV setting based on PEEP-FiO2 table according to ARDS Network. At end expiration, PEEP can be adjusted until the $\mathrm{P}_{\mathrm{L}}$ become positive and should not exceed $10 \mathrm{~cm} \mathrm{H}_{2} \mathrm{O}$ to keep airway opening and avoid overstretch. At end inspiration, set tidal volume are limited to keep $\mathrm{P}_{\mathrm{L}}$ less than $25 \mathrm{~cm} \mathrm{H}_{2} \mathrm{O}(12,55)$. However, some authors have debated using the absolute pressure and preferred using the variation of the Peso rather than the absolute value to estimate lung stress namely elastance derived method calculating chest wall elastance (Ecw) which is the ratio of Pressure difference across chest wall $(\Delta \mathrm{Pcw}) / \mathrm{VT}$. Under static condition, $\mathrm{P}_{\mathrm{L}}=\operatorname{Paw} \mathrm{x}\left(\mathrm{E}_{\mathrm{L}} / \mathrm{E}_{\mathrm{RS}}\right)$ in which $\mathrm{E}_{\mathrm{L}}=\Delta \mathrm{P}_{\mathrm{L}} / \mathrm{VT}$ and $\mathrm{E}_{\mathrm{RS}}=\Delta \mathrm{Paw} / \mathrm{V}_{\mathrm{T}}(52)$. Peso can distinguish the fraction of airway pressure that overcome lung or chest wall elastance.

\subsection{Ultrasound in ICU and Perioperative period}

In ARDS, the presence of pulmonary vascular dysfunction and extravascular lung water are associated with higher mortality (56). Although some methods, i.e. pulse pattern analysis and transpulmonary thermodilution technique can provide the hemodynamic goal directed therapy and respiratory variables as well as extravascular lung water (EVLW) index in either ICU or high risk surgical patients. Nevertheless, these techniques are invasive. Regarding the availability and noninvasiveness of bedside ultrasound and echocardiography, lung ultrasound can estimate EVLW index and evaluate the response of PEEP titration in ARDS (57). Jambrik et al. have demonstrated that there is significant correlation between numbers of B-lines (58) and wet to dry ratio measured by gravimetric method $(r=0.91, p<0.001)$. Corradi et al. have demonstrated that quantitative lung ultrasound, based on a video gray scale analysis correlated with the amount of EVLW (59). Furthermore, the pleural effusion could be defined by the presence of anechoic or hypoechoic homogenous structure (60). In moderate to severe ARDS, the prevalence of cor-pulmonale diagnosed by trans- 
-esophageal echocardiography is $22 \%$ despite low level of PEEP. Bedside echocardiography can be used to evaluate the right ventricular and biventricular cardiac function. During perioperative period, we can early detect atelectasis by the presence of hyper echoic hepatization suggesting the presence of consolidation. Furthermore, the measurement of air column width of larynx during endotracheal cuff deflation is the good predictor of post-extubation laryngeal edema and may predict post-operative intubation (61).

\section{Protective ventilation in non-injured lung}

The beneficial effects of protective ventilation with lower tidal volume and higher PEEP were clearly established by ARDS Network 15 years ago (62). Protective ventilation (PV) for non-injured lung has been studied in a contest of ICU and perioperative period.

Lee et al. firstly studied the role of protective ventilations in 103 ICU patients with non-injured lungs (63). The main outcome of this study was the duration of mechanical ventilation that was lower in patients treated with protective ventilation (2.30 days vs. 3.90 days) (63). Gajic et al. evaluated the effect of PV in a cohort study on 166 patients without lung injury and admitted in ICU (64). The authors did not report significant differences in development of lung injury between the groups (64). Wolthuis et al. showed the effects of $\mathrm{PV}$ in lowering sedative use, as primary outcome, in non-injured lung patients (65). In this study the authors did not find significant difference between the groups (65). Yilmaz et al. performed a cohort study on 375 ICU patients to evaluate the role of PV on prevention of lung injury as primary outcome (66). The authors did not find difference between protective and conventional ventilation about the considered outcome (66). Determann et al. and Pinheiro de Oliveira et al.performed randomized controlled trials to assess the levels of cytokine in broncho-alveolar lavage (BAL) in patient treated with protective and conventional ventilation $(67,68)$. Interestingly, Determann et al. did not show any differences in cytokine in BAL, while Pinheiro de Oliveira et al. demonstrated a higher level of Cytokine in BAL in protective than in conservative ventilation (168 pg/ml vs.72 pg/ml) $(67,68)$.

Protective ventilation was also studied in a perioperative setting on healthy lungs. It has been reported that $5 \%$ to $10 \%$ of major abdominal and thoracic surgery developed postoperative pulmonary complications (69). Different randomized controlled trials (RCTs) have been performed in major abdominal surgery on PV with different outcomes. Determann et al. did not find any differences in BAL and plasma inflammation proteins between protective and conventional ventilation (70). Wolthuis at el. reported a reduction in BAL myeloperoxidase using PV in healthy patients underwent abdominal surgery (70). Weingarten et al. experienced a better oxygenations but no improvement of inflammatory biomarkers in a RCT on patients aged $>65$ years (70). Treschan et al. evaluated the effectiveness of PV in 101 healthy lung patients (71). In this study, there was no difference in improving lung function between protective and conventional ventilation (71). Recently, Severgnini et al. performed a RCT evaluating the role of PV in major abdominal surgery (10). The authors reported an improvement in pulmonary function and modified clinical pulmonary infection score (mCPIS) and a reduction in X-ray chest findings in patients treated with PV during surgery (10). Futier et al. performed a large RCT on 400 patients submitted to major abdominal surgery with protective and conventional ventilation (9). The authors found a reduced incidence of pulmonary and extrapulmonary complications in PV group (9). Protective ventilation was also matter of study in cardiac surgeries. In coronary artery bypass surgery, three studies did not demonstrate any difference in plasma and BAL cytokine levels using PV $(72,73,74)$. Sundar et al. performed a RCT on PV in cardiac surgery on 149 patients (75). The authors found less incidence of re-intubation and a faster weaning at 6-8 hours after surgery in patients treated with PV )75).

Protective ventilation in non-injured lung was also evaluated in different meta-analysis including ICU and perioperative studies. In meta-analysis by Serpa-Neto et al., the authors included 20 studies, but only 15 RCT, and 2833 ICU and surgical patients (76). In this meta-analysis, PV had a tidal volume of $6.5 \mathrm{ml} / \mathrm{kg}$ and PEEP of $6.4 \mathrm{~cm} \mathrm{H}_{2} \mathrm{O}$ while conventional ventilation with tidal volume of $10.6 \mathrm{ml} / \mathrm{kg}$ and PEEP of 3.4 $\mathrm{cm} \mathrm{H}_{2} \mathrm{O}$. Among patients without lung injury, PV was associated with better outcomes as acute lung injury (RR 0.33 ; $95 \%$ CI $0.23-0.47$ ), pulmonary infection (RR 0.52; $95 \%$ CI 0.33-0.82), atelectasis (RR 0.62; 95 $\% \mathrm{CI} 0.41-0.95$ ) and mortality (RR $0.64 ; 95 \% \mathrm{CI}$ 0.46-0.86) (76). In the meta-analysis by Hemmes et al., the authors included 8 studies. But 6 RCT, and 169 surgical patients without lung injury (77). PV was performed with $6.1 \mathrm{ml} / \mathrm{kg}$ mean tidal volume and $6.6 \mathrm{~cm}$ $\mathrm{H}_{2} \mathrm{O}$ PEEP while conventional ventilation with 10.4 $\mathrm{ml} / \mathrm{kg}$ tidal volume and $2.7 \mathrm{~cm} \mathrm{H}_{2} \mathrm{O}$ PEEP (77). In this study PV protected against postoperative complications as acute lung injury (RR 0.40; $95 \%$ CI 0.22-0.70) pulmonary infection (RR 0.64; $95 \%$ CI $0.43-0.97$ ) and atelectasis (RR 0.67; $95 \%$ CI 0.47-0.96) (77). A recent meta-analysis by Sutherasan et al. included 17 studies as RCT and 1,362 ICU and surgical patients (78). In this study PV was set with mean tidal volume of 6.1 
$\mathrm{ml} / \mathrm{kg}$ and PEEP of $7.6 \mathrm{~cm} \mathrm{H}_{2} \mathrm{O}$ while conventional ventilation with mean tidal volume of $10.7 \mathrm{ml} / \mathrm{kg}$ and PEEP of $2.5 \mathrm{~cm} \mathrm{H}_{2} \mathrm{O}$ (78). This meta-analysis suggested that among surgical and critically ill patients without lung injury, protective mechanical ventilation with use of lower VT, with or without PEEP, is associated with better clinical pulmonary outcomes in term of ARDS incidence (RR 0.27; $95 \%$ CI 0.12-0.59) and pulmonary infection (RR 0.35 ; $95 \%$ CI $0.25-0.63$ ) but does not decrease atelectasis (RR 0.76; $95 \%$ CI $0.33-1.37$ ), mortality (RR $1.03 ; 95 \%$ CI $0.67-1.58$ ) or length of stay in ICU or hospital (WMD $-0.40 ; 95 \% \mathrm{CI}$ $-1.02 ; 0.22$. WMD $0.13 ; 95 \% \mathrm{CI}-0.73 ; 0.08)$ (78).

\section{Protective ventilation in ARDS}

Protective ventilation is a supportive tool for patients with acute lung injury. In this setting, PV was extensively studied across the years. PV included low tidal volume, high PEEP and in some circumstances recruitment maneuvers.

In the 1998, Amato et al. performed a multicenter RCT to evaluate the effects of low tidal volume (6 $\mathrm{ml} / \mathrm{kg}$ ) on mortality, barotrauma and multiple organ failure (MOF) in a cohort of ARDS patients (79). PV, compared with conventional ventilation, was associated with improved survival at 28 days, higher rate of weaning from mechanical ventilation, and lower rate of barotrauma in patients with ARDS although it was not associated with higher rate of survival to hospital discharge (79). Brochard et al. and Brower et al. in prospective RCTs evaluated the effect of low tidal volume $(7 \mathrm{ml} / \mathrm{kg}$ and $8 \mathrm{ml} / \mathrm{kg}$ ) in ARDS patients in mortality, duration of mechanical ventilation and barotraumas $(80,81)$. Both studies concluded that there were no effects of PV on considered outcomes $(80,81)$. In the 2000, the ARDS network group performed a large RCT including 861 adult ARDS patients to assess the role of low tidal volume $(6 \mathrm{~m} / \mathrm{kg})$ different outcomes as mortality, MOF, duration of mechanical ventilation, barotrauma and ventilator free days (62). In this study the authors concluded that in ARDS patients mechanical ventilation with a lower tidal volume, than is traditionally used, resulted in decreased mortality and increases the number of days without ventilator use (62). In the 2004, the ARDS network performed another study to evaluate the effect of higher versus lower PEEP in ARDS patients on the same previous outcomes (81). In this study, PV was set high PEEP 5-25 $\mathrm{cm} \mathrm{H}_{2} \mathrm{O}$ according $\mathrm{FiO}_{2}$ while conventional ventilation with low PEEP $5 \mathrm{~cm} \mathrm{H}_{2} \mathrm{O}$ (82). This study found no difference in the considered outcome when high PEEP level was compared with low PEEP (82). PV with high and low PEEP levels was matter of study in three different RCTs performed in $2008(55,83,84)$. In the study by
Meade et al., high PEEP level was fixed between 5-25 $\mathrm{cm} \mathrm{H}_{2} \mathrm{O}$ according $\mathrm{FiO}_{2}$ and low PEEP level at $5 \mathrm{~cm}$ $\mathrm{H}_{2} \mathrm{O}$ (83). In the study by Mercat et al. high PEEP was chosen according to Plateau pressure of $28-30 \mathrm{~cm} \mathrm{H}_{2} \mathrm{O}$ and low PEEP between 5-9 $\mathrm{cm} \mathrm{H}_{2} \mathrm{O}$ (84). Talmor et al. fixed the high PEEP level at $17 \mathrm{~cm} \mathrm{H}_{2} \mathrm{O}$ and the low PEEP level at $10 \mathrm{~cm} \mathrm{H}_{2} \mathrm{O}(55,29)$. In these studies high PEEP did not affect mortality $(55,83,84)$. Interestingly, while Mercat et al. found an improvement in lung function and a reduction of MOF and duration of mechanical ventilation; Meade et al. did not confirm these findings $(83,84)$. Furthermore, the conclusion by Talmor et al, was very interesting because the authors suggested the use of mechanical ventilation guided by esophageal pressure to further improve oxygenation and compliance in ARDS patients (29). Recently a meta-analysis evaluated the effects of high versus low PEEP in ARDS patients considering 7 RCTs and 2565 ARDS patients (15). The outcomes were mortality, oxygenation, barotrauma and length of stay in ICU (15). High PEEP did not affect mortality, barotrauma and length of stay in ICU but improved the oxygenation of ARDS patients at 1, 3 and 7 days (15).

\section{Other adjunctive rescue strategies for ARDS}

\subsection{Prone positioning}

Prone position is the adjunctive treatment that can improve oxygenation in $70 \%$ of patients. The mechanisms are an increase in end-expiratory lung volume, improvement of ventilation-perfusion matching and decrease of mass effect of the heart at the lower lobes as well as an increased homogeneity of ventilation (11).

Recent randomized controlled trial has demonstrated that in patients with $\mathrm{PaO}_{2} / \mathrm{FiO}_{2}$ less than 150 when receiving $\mathrm{FiO}_{2}$ of $60 \%$, patients who received prone position showed the decrease in mortality than in supine position (28-day mortality; $16 \%$ vs. $32.8 \%$, respectively) (85). Moreover, recent meta-analysis including this RCT have demonstrated that prone position with low tidal volume ventilation in severe ARDS patients significantly decrease 60-day mortality (86). In the subgroup which the duration of prone positioning was more than 10 hours per session showed markedly reduced in overall mortality compared with the shorter duration groups (87). However, the risk of pressure ulcer and major airways problems should be considered during implementing the prone positioning protocol (87).

\subsection{Extracorporeal membrane oxygenation}

Extracorporeal membrane oxygenation (ECMO) have shown the increase of survival in severe ARDS 
Table 1. Strategies for prevention and management patients with ARDS and without ARDS

\begin{tabular}{|c|c|c|}
\hline & Patients with ARDS & $\begin{array}{l}\text { Patients without ARDS in ICU } \\
\text { Patients undergoing high risk } \\
\text { surgery i.e. intra-abdominal } \\
\text { surgery }\end{array}$ \\
\hline $\begin{array}{l}\text { Risk factors for further VALI } \\
\text { and postoperative pulmonary } \\
\text { complications }\end{array}$ & $\begin{array}{l}\text { - Sepsis } \\
\text { - Fluid loading } \\
\text { - Blood transfusion } \\
\text { - Old age }\end{array}$ & $\begin{array}{l}\text { - Underlying status } \\
\text { - Type of anaesthesia } \\
\text { - Type of surgery i.e. cardio- } \\
\text { pulmonary surgery and } \\
\text { abdominal surgery } \\
\text { - Smoking status }\end{array}$ \\
\hline Protective ventilation & $\begin{array}{l}\text { - Tidal volume } 6 \mathrm{ml} / \mathrm{kg} \mathrm{PBW} \\
\text { - Plateau pressure }=30 \mathrm{cmH}_{2} \mathrm{O} \\
\text { - } \mathrm{PEEP} \text { according to } \mathrm{PEEP} / \mathrm{FiO}_{2} \\
\text { table or titration by respiratory } \\
\text { mechanics and/or oesophageal } \\
\text { pressure } \\
\text { - Recruitment maneuver }\end{array}$ & 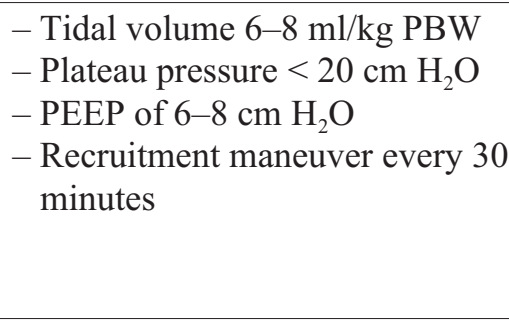 \\
\hline Oesophageal pressure monitoring & $\begin{array}{l}\text { - Obesity, pleural effusion, } \\
\text { intra-abdominal hypertension, } \\
\text { ARDS, massive ascites }\end{array}$ & $\begin{array}{l}\text { - High risk abdominal surgery, } \\
\text { obesity }\end{array}$ \\
\hline Other effective strategies & $\begin{aligned} & \text { - Prone position when } \\
& \mathrm{PaO}_{2} / \mathrm{FiO}_{2}<150 \mathrm{mmHg} \text { and } \\
& \mathrm{PEEP}>10 \mathrm{~cm} \mathrm{H}_{2} \mathrm{O} \\
& \text { - Extracorporeal membrane } \text { oxygenation } \\
& \text { - Neuromuscular blocking agents }\end{aligned}$ & $\begin{array}{l}\text { - Perioperative physiotherapy } \\
\text { - Noninvasive ventialtion }\end{array}$ \\
\hline Predictive scores & LIPS score & $\begin{array}{l}\text { ARISCAT, SLIP, PRF and } \\
\text { SPORC }\end{array}$ \\
\hline
\end{tabular}

Abbreviations: ARDS: Acute Respiratory Distress Syndrome; ICU: intensive care unit; VALI: ventilator associated lung injury; PEEP: positive end expiratory pressure; PBW: Predicted body weight; LIPS: lung injury prediction score; PRF: postoperative respiratory failure index; ARISCAT: Postoperative pulmonary complications risk score; SLIP: Surgical lung injury prediction score; SPORC: Score for Prediction of Postoperative Respiratory Complications

$\left(\mathrm{PaO}_{2} / \mathrm{FIO}_{2} \leq 100\right.$ and $\left.\mathrm{PEEP} \geq 5-10 \mathrm{~cm} \mathrm{H}_{2} \mathrm{O}\right)$. To avoid further VALI in ARDS and complications from ECMO itself, another approach is bridging MV with extracorporeal membrane oxygenation. During applying EC$\mathrm{MO}$, the VT can be decreased until less than $6 \mathrm{ml} / \mathrm{kg}$ PBW ("ultra" protective MV) (85).

Strategies for prevention and management patients with ARDS and without ARDS are summarized in Table 1.

\section{Methods for prevention of ventilator associated lung injury and postoperative pulmonary complications}

\subsection{Risk factors for ARDS and ventilator associated lung injury}

In severe sepsis patients present at emergency department, high lactate, lung injury prediction scores and microbiological proven infection are independent risk factors for the development of ARDS (88). Other factors i.e. hypoalbuminemia, chemotherapy, obesity and diabetic mellitus have been proposed as the risk factors of ARDS. Gajic el al have validated lung injury prediction score (LIPS) to identify the high risk patients at the time of hospital admission and can discriminate the patients who developed ARDS from those who did not with an AUC of ROC at $0.80(95 \% \mathrm{CI}$; $0.78-0.82)(89)$. The variables that were included in calculated worksheet composed of previously mentioned factors, type of surgery and trauma.

Several factors have been proven as the predisposing factors of VALI i.e. sepsis, fluid loading, blood transfusion and age. Old animals are more susceptible to VALI with high VT and constant PEEP compared with younger animals associated with the increase amount of lung lavage protein, IL-6 concentration, and increase of lung wet to dry ratios (90). Transfusion-related acute lung injury (TRALI) is the reaction of the 
transfusion of antibodies against the recipients' antigen that accumulate during blood storage which aggravate lung injury. TRALI combined with injurious MV setting may aggravate further lung injury, particularly transfusion blood with longer storage duration in septic patients (91).

\subsection{Role of recent predictive scores}

PPCs are associated with various risk factors namely underlying status, type of anaesthesia and surgery particularly cardiopulmonary surgery and abdominal surgery as well as smoking status.

Several investigators have developed different scores to predict the risk of PPCs. The parameters required for score calculation can be assessed preoperatively and during bedside evaluation.

\subsubsection{Post-operative respiratory failure risk index and pneumonia risk index}

Based on National Surgical Quality Improvement Program (NSQIP) data, postoperative respiratory failure (PRF) index was developed by the investigators from veterans' affair in non-cardiac surgery patients. The risk factors were including the type of surgery, age, functional status and COPD. The laboratory data comprised albumin level less than $30 \mathrm{~g} / \mathrm{L}$, and blood urea nitrogen level more than $30 \mathrm{mg} / \mathrm{dL}$ in the model (92). The same group has constructed another index, postoperative pneumonia risk index that are added the data of impaired sensorium, cerebral vascular accident, transfusion, long-term steroid use, smoking, and alcohol use to previously mentioned index (93). These indexes have a limitation that the majority of populations included in the analysis are male veterans therefore these indexes may not be used generalizability.

\subsubsection{Postoperative pulmonary complications risk score (ARISCAT score)}

Canet et al. have identified the seven independent risk factors including low pre-operative arterial oxygen saturation, recent acute respiratory infection, age, anemia, upper abdominal or intra thoracic surgery, surgical duration of at least $2 \mathrm{~h}$, and emergency surgery and showed that the AUCs under ROC curve of this score are $90 \%$ for the development of PPCs predictive index and $80 \%$ from the validation of this index (53). The PERISCOPE (Prospective Evaluation of a Risk Score for Postoperative Pulmonary Complications in Europe) study is completed and will show the data of external validation of this score (94).

\subsubsection{Surgical lung injury prediction score (SLIP score)}

The surgical lung injury prediction score (the SLIP score) were developed to classify the patients who at risk for postoperative ARDS in patients with high-risk surgery and require mechanical ventilation during general anaesthesia for longer than 3 hours with an AUC of 0.82 (95\% CI 0.78-0.86). The score includes diabetes, COPD, GERD, alcohol abuse and type of surgery. However, this study is conducted in single centre and retrospective study (95).

\subsubsection{Score for Prediction of Postoperative Respiratory Complications (SPORC)}

Another recent score that developed to predict postoperative re-intubation is Score for Prediction of Postoperative Respiratory Complications (SPORC) within the first 3 postoperative days. Four independent predictors contribute to an American Society of Anesthesiologists (ASA) score $\geq 3$ : emergency surgery, high-risk surgical service, history of congestive heart failure and chronic pulmonary disease (96).

\section{CONCLUSION}

Protective ventilation has been proven preventing further complications i.e. VALI, postoperative pulmonary complications in either ARDS or non-injured lungs. Predictive scores and bedside respiratory monitoring i.e. ultrasound and esophageal pressure measurement are crucial tools to identify at risk patients and minimize further VALI as well as PPCs.

\section{Abbreviations}

AECC - American-European Consensus Conference

PPCs - Postoperative pulmonary complications

ARDS - Acute Respiratory Distress Syndrome

VALI - Ventilator associated lung injury

PEEP - Positive end expiratory pressure

ICU - Intensive care unit

MV - Mechanical ventilation

PL - Transpulmonary pressure

VT - Tidal volume

TLRs - Toll-like receptors

NF-kappaB - Nuclear factor kappa B

TNF - Tumor necrosis factor

IL - Interleukins

ECM - Extracellular matrix

Pplat - Plateau pressure

FRC - Functional residual capacity 


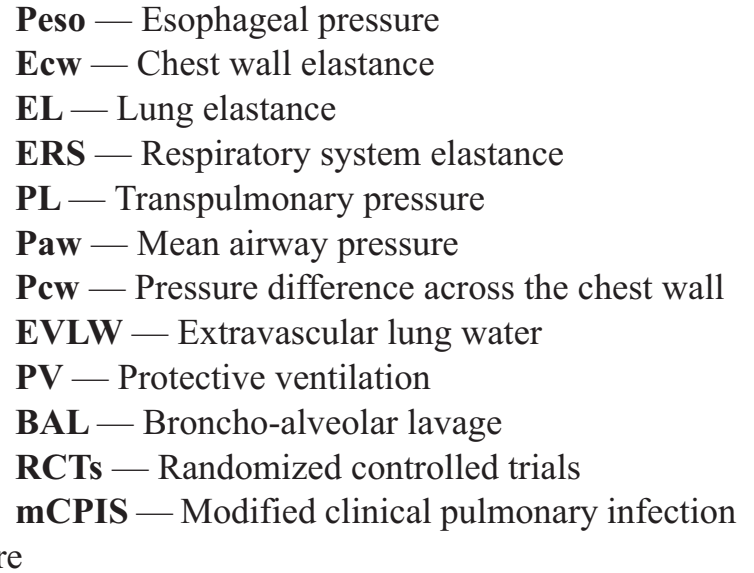

MOF - Multiple organ failure

ECMO - Extracorporeal membrane oxygenation

LIPS - Lung injury prediction score

TRALI - Transfusion-related acute lung injury

NSQIP - National Surgical Quality Improvement Program

PRF - Postoperative respiratory failure

the SLIP score - Surgical lung injury prediction score

SPORC - Score for Prediction of Postoperative Respiratory Complications

ASA - American Society of Anesthesiologists

\title{
Sažetak
}

\section{PROTEKTIVNA MEHANIČKA VENTILACIJA KOD PACIJENATA SA ILI BEZ POVREDE PLUĆA}

\author{
Sutherasan Yuda, ${ }^{1,2}$ Vargas Maria, ${ }^{3}$ Rodríguez-González Raquel, ${ }^{4,5}$ Pelosi Paolo ${ }^{1}$ \\ ${ }^{1}$ Department of Surgical Sciences and Integrated Diagnostics, University of Genoa, IRCCS San Martino — IST, Genoa, Italy \\ ${ }^{2}$ Ramathibodi Hospital, Mahidol University, Bangkok, Thailand \\ ${ }^{3}$ Department of Neuroscience and Reproductive and Odontostomatological Sciences, University of Naples "Federico II", Italy \\ ${ }^{4}$ Multidisciplinary Organ Dysfunction Evaluation Research Network, Research Unit, \\ Hospital Universitario Dr. Negrín, Las Palmas de Gran Canaria, Spain \\ ${ }^{5}$ Critical Patient Translational Research Group, Department of Anesthesiology, Intensive Care and Pain Management, \\ Hospital Clínico Universitario, Instituto de Investigación Sanitaria (IDIS), University of Santiago de Compostela, \\ Santiago de Compostela, Spain
}

Smrtnost od Sindroma Akutnog Respiratornog Distresa (ARDS) je još uvek visoka i kreće se od 27 do $45 \%$ prema Berlinskoj definiciji. Čak i kod hirurških pacijenata bez povrede pluća, postoperativne plućne komplikacije (PPC) su česte. Kod ARDS-a, protektivna ventilacija sa niskim „tidal“ volumenom od $6 \mathrm{ml} / \mathrm{kg}$ PBW i višim nivoima pozitivnog end-ekspiratornog pritiska (PEEP) su široko prihvaćeni kao rutinska praksa. Kod pacijenata bez ARDS-a, podvrgnutih mehaničkoj ventilaciji, protektivna ventilacija sa niskim „tidal“ volumenom od $6 \mathrm{ml} / \mathrm{kg}$ PBW i niskim do srednjim PEEPom su postali nov izazov suportivne nege posebno u jedinicama intenzivne nege i kod perioperativnih pacijenata.

\section{REFERENCES}

1. Villar J, Sulemanji D, Kacmarek RM. The acute respiratory distress syndrome: incidence and mortality, has it changed? Current opinion in critical care. 2014; 20(1): 3-9.

2. Force ADT, Ranieri VM, Rubenfeld GD, et al. Acute respiratory distress syndrome: the Berlin Definition. JAMA : the journal of the American Medical Association. 2012; 307(23): 2526-33.

3. Kushimoto S, Endo T, Yamanouchi S, et al. Relationship between extravascular lung water and severity categories of acute respiratory distress syndrome by the Berlin definition. Critical care. 2013; 17(4): 132.
Respiratorni monitorig je od velike pomoći za podešavanje optimalne ventilacije kako bi se prevenirala povrede usled asistirane ventilacije i na vreme detektovale postoperativne plućne komplikacije u perioperativnom periodu. Nekoliko rezultata je usvojeno kako bi se smanjio rizik od ARDS, PPC i VALI (ventilator associated lung injury). Vreme je za primenu bazične fiziologije respiratorne funkcije i na dokazima zasnovane prakse kako bi se unapredili ishodi ARDS-a i PPC.

Ključne reči: asistirana ventilacija, Akutni Respiratorni Distres Sindrom, transpulmonarni pritisak, Positivni End Ekspiratorni Pritisak, Protektivna ventilacija, Respiratorni monitoring.

4. Barbas CS, Isola AM, Caser EB. What is the future of acute respiratory distress syndrome after the Berlin definition? Current opinion in critical care. 2014; 20(1): 10-6.

5. Thille AW, Esteban A, Fernandez-Segoviano P, et al. Comparison of the Berlin definition for acute respiratory distress syndrome with autopsy. American journal of respiratory and critical care medicine. 2013; 187(7): 761-7.

6. Pearse RM, Moreno RP, Bauer P, et al. Mortality after surgery in Europe: a 7 day cohort study. Lancet. 2012; 380(9847): 1059-65.

7. Smetana GW, Lawrence VA, Cornell JE, American College of P. Preoperative pulmonary risk stratification for noncardiot- 
horacic surgery: systematic review for the American College of Physicians. Annals of internal medicine. 2006; 144(8): 581-95.

8. Futier E, Constantin J, Jaber S. Protective lung ventilation in operating room: Systematic Review. Minerva anestesiologica. 2013; 79(11): 1306-12.

9. Futier E, Constantin JM, Paugam-Burtz C, et al. A trial of intraoperative low-tidal-volume ventilation in abdominal surgery. The New England journal of medicine. 2013; 369(5): 428-37.

10. Severgnini P, Selmo G, Lanza C, et al. Protective mechanical ventilation during general anesthesia for open abdominal surgery improves postoperative pulmonary function. Anesthesiology. 2013; 118(6): 1307-21.

11. Slutsky AS, Ranieri VM. Ventilator-induced lung injury. The New England journal of medicine. 2013; 369(22): 2126-36.

12. Gattinoni L, Carlesso E, Caironi P. Stress and strain within the lung. Current opinion in critical care. 2012; 18(1): 42-7.

13. Sutherasan Y, D'Antini D, Pelosi P. Advances in ventilator-associated lung injury: prevention is the target. Expert review of respiratory medicine. 2014; 8(2): 233-48.

14. Protti A, Cressoni M, Santini A, et al. Lung stress and strain during mechanical ventilation: any safe threshold? American journal of respiratory and critical care medicine. 2011; 183(10): 1354-62.

15. Santa Cruz R, Rojas JI, Nervi R, Heredia R, Ciapponi A. High versus low positive end-expiratory pressure (PEEP) levels for mechanically ventilated adult patients with acute lung injury and acute respiratory distress syndrome. The Cochrane database of systematic reviews. 2013; 6:CD009098.

16. Tremblay L, Valenza F, Ribeiro SP, Li J, Slutsky AS. Injurious ventilatory strategies increase cytokines and c-fos m-RNA expression in an isolated rat lung model. The Journal of clinical investigation. 1997; 99(5): 944-52.

17. Dos Santos CC, Slutsky AS. Invited review: mechanisms of ventilator-induced lung injury: a perspective. Journal of applied physiology. 2000; 89(4): 1645-55.

18. Gattinoni L, Protti A, Caironi P, Carlesso E. Ventilator-induced lung injury: the anatomical and physiological framework. Critical care medicine. 2010; 38(10 Suppl 1): S539-48.

19. Oeckler RA, Hubmayr RD. Ventilator-associated lung injury: a search for better therapeutic targets. The European respiratory journal. 2007; 30(6): 1216-26.

20. Kuchnicka K, Maciejewski D. Ventilator-associated lung injury. Anaesthesiology intensive therapy. 2013; 45(3): 164-70.

21. Kawai T, Akira S. The role of pattern-recognition receptors in innate immunity: update on Toll-like receptors. Nature immunology. 2010; 11(5): 373-84.

22. Held HD, Boettcher S, Hamann L, Uhlig S. Ventilation-induced chemokine and cytokine release is associated with activation of nuclear factor-kappaB and is blocked by steroids. American journal of respiratory and critical care medicine. 2001; 163(3 Pt 1): 711-6.

23. Moriyama K, Ishizaka A, Nakamura M, et al. Enhancement of the endotoxin recognition pathway by ventilation with a large tidal volume in rabbits. American journal of physiology Lung cellular and molecular physiology. 2004; 286(6): 1114-21.

24. Halbertsma FJ, Vaneker M, Scheffer GJ, van der Hoeven JG. Cytokines and biotrauma in ventilator-induced lung injury: a critical review of the literature. The Netherlands journal of medicine. 2005; 63(10): 382-92.
25. Jiang D, Liang J, Fan J, et al. Regulation of lung injury and repair by Toll-like receptors and hyaluronan. Nature medicine. 2005; 11(11): 1173-9.

26. Piccinini AM, Midwood KS. DAMPening inflammation by modulating TLR signalling. Mediators of inflammation, vol. 2010, Article ID 672395, 21 pages, 2010. doi: 10.1155/2010/67239527.

27. Pelosi P, Negrini D. Extracellular matrix and mechanical ventilation in healthy lungs: back to baro/volotrauma? Current opinion in critical care. 2008; 14(1): 16-21.

28. Moriondo A, Pelosi P, Passi A, et al. Proteoglycan fragmentation and respiratory mechanics in mechanically ventilated healthy rats. Journal of applied physiology. 2007; 103(3): $747-56$.

29. Bai KJ, Spicer AP, Mascarenhas MM, et al. The role of hyaluronan synthase 3 in ventilator-induced lung injury. American journal of respiratory and critical care medicine. 2005; 172(1): 92-8.

30. Reddy SP, Hassoun PM, Brower R. Redox imbalance and ventilator-induced lung injury. Antioxidants \& redox signaling. 2007; 9(11): 2003-12.

31. Ngiam N, Kavanagh BP. Ventilator-induced lung injury: the role of gene activation. Current opinion in critical care. 2012; 18(1): 16-22.

32. Chapman KE, Sinclair SE, Zhuang D, Hassid A, Desai LP, Waters CM. Cyclic mechanical strain increases reactive oxygen species production in pulmonary epithelial cells. American journal of physiology Lung cellular and molecular physiology. 2005; 289(5): 834-41.

33. Syrkina O, Jafari B, Hales CA, Quinn DA. Oxidant stress mediates inflammation and apoptosis in ventilator-induced lung injury. Respirology. 2008; 13(3): 333-40.

34. Cheng YJ, Chan KC, Chien CT, Sun WZ, Lin CJ. Oxidative stress during 1-lung ventilation. The Journal of thoracic and cardiovascular surgery. 2006; 132(3): 513-8.

35. Jafari B, Ouyang B, Li LF, Hales CA, Quinn DA. Intracellular glutathione in stretch-induced cytokine release from alveolar type-2 like cells. Respirology. 2004; 9(1): 43-53.

36. Huang CS, Kawamura T, Lee S, et al. Hydrogen inhalation ameliorates ventilator-induced lung injury. Critical care. 2010; 14(6): R234.

37. Bem RA, van Woensel JB, Bos AP, et al. Mechanical ventilation enhances lung inflammation and caspase activity in a model of mouse pneumovirus infection. American journal of physiology Lung cellular and molecular physiology. 2009; 296(1): 46-56.

38. Huang CS, Kawamura T, Peng X, et al. Hydrogen inhalation reduced epithelial apoptosis in ventilator-induced lung injury via a mechanism involving nuclear factor-kappa B activation. Biochemical and biophysical research communications. 2011; 408(2): 253-8.

39. Oeckler RA, Hubmayr RD. Cell wounding and repair in ventilator injured lungs. Respiratory physiology \& neurobiology. 2008; 163(1-3): 44-53.

40. Korpos E, Wu C, Sorokin L. Multiple roles of the extracellular matrix in inflammation. Current pharmaceutical design. 2009; 15(12): 1349-57.

41. Madri JA, Graesser D. Cell migration in the immune system: the evolving inter-related roles of adhesion molecules and proteinases. Developmental immunology. 2000; 7(2-4): 103-16.

42. Gonzalez-Lopez A, Astudillo A, Garcia-Prieto E, et al. Inflammation and matrix remodeling during repair of ventila- 
tor-induced lung injury. American journal of physiology Lung cellular and molecular physiology. 2011; 301(4): 500-9.

43. Villar J, Cabrera NE, Valladares F, et al. Activation of the Wnt/beta-catenin signaling pathway by mechanical ventilation is associated with ventilator-induced pulmonary fibrosis in healthy lungs. PloS one. 2011; 6(9): 23914.

44. Chimenti L, Luque T, Bonsignore MR, Ramirez J, Navajas D, Farre R. Pre-treatment with mesenchymal stem cells reduces ventilator-induced lung injury. The European respiratory journal. 2012; 40(4): 939-48.

45. Liang ZD, Yin XR, Cai DS, Zhou H, Pei L. Autologous transplantation of adipose-derived stromal cells ameliorates ventilator-induced lung injury in rats. Journal of translational medicine. 2013; 11(1): 179.

46. Curley GF, Hayes M, Ansari B, et al. Mesenchymal stem cells enhance recovery and repair following ventilator-induced lung injury in the rat. Thorax. 2012; 67(6): 496-501.

47. Frank JA, Parsons PE, Matthay MA. Pathogenetic significance of biological markers of ventilator-associated lung injury in experimental and clinical studies. Chest. 2006; 130(6): 1906-14.

48. Ware LB, Koyama T, Zhao Z, et al. Biomarkers of lung epithelial injury and inflammation distinguish severe sepsis patients with acute respiratory distress syndrome. Critical care. 2013; 17(5): 253.

49. Izquierdo-Garcia JL, Naz S, Nin N, et al. A Metabolomic Approach to the Pathogenesis of Ventilator-induced Lung Injury. Anesthesiology. 2014; 120(3): 694-702.

50. Terragni PP, Filippini C, Slutsky AS, et al. Accuracy of plateau pressure and stress index to identify injurious ventilation in patients with acute respiratory distress syndrome. Anesthesiology. 2013; 119(4): 880-9.

51. Grasso S, Terragni P, Birocco A, et al. ECMO criteria for influenza A (H1N1)-associated ARDS: role of transpulmonary pressure. Intensive care medicine. 2012; 38(3): 395-403.

52. Akoumianaki E, Maggiore SM, Valenza F, et al. The Application of Esophageal Pressure Measurement in Patients with Respiratory Failure. American journal of respiratory and critical care medicine. 2014.

53. Canet J, Gallart L, Gomar C, et al. Prediction of postoperative pulmonary complications in a population-based surgical cohort. Anesthesiology. 2010; 113(6): 1338-50.

54. Ball L, Sutherasan Y, Pelosi P. Monitoring respiration: what the clinician needs to know. Best practice $\&$ research Clinical anaesthesiology. 2013; 27(2): 209-23.

55. Talmor D, Sarge T, Malhotra A, et al. Mechanical ventilation guided by esophageal pressure in acute lung injury. The New England journal of medicine. 2008; 359(20): 2095-104.

56. Jaecklin T, Engelberts D, Otulakowski G, O'Brodovich H, Post M, Kavanagh BP. Lung-derived soluble mediators are pathogenic in ventilator-induced lung injury. American journal of physiology Lung cellular and molecular physiology. 2011; 300(4): L648-58.

57. Bouhemad B, Brisson H, Le-Guen M, Arbelot C, Lu Q, Rouby JJ. Bedside ultrasound assessment of positive end-expiratory pressure-induced lung recruitment. American journal of respiratory and critical care medicine. 2011; 183(3): 341-7.

58. Jambrik Z, Gargani L, Adamicza A, et al. B-lines quantify the lung water content: a lung ultrasound versus lung gravimetry study in acute lung injury. Ultrasound in medicine \& biology. 2010; 36(12): 2004-10.

59. Corradi F, Ball L, Brusasco C, et al. Assessment of extravascular lung water by quantitative ultrasound and $\mathrm{CT}$ in iso- lated bovine lung. Respiratory physiology \& neurobiology. 2013; 187(3): 244-9.

60. Corradi F, Brusasco C, Pelosi P. Chest ultrasound in acute respiratory distress syndrome. Current opinion in critical care. 2013.

61. Sutherasan Y, Theerawit P, Hongphanut T, Kiatboonsri $\mathrm{C}$, Kiatboonsri S. Predicting laryngeal edema in intubated patients by portable intensive care unit ultrasound. Journal of critical care. 2013 ; 28(5): 675-80.

62 . Ventilation with lower tidal volumes as compared with traditional tidal volumes for acute lung injury and the acute respiratory distress syndrome. The Acute Respiratory Distress Syndrome Network. The New England journal of medicine. 2000; 342(18): 1301-8.

63. Lee PC, Helsmoortel CM, Cohn SM, Fink MP. Are low tidal volumes safe? Chest. 1990; 97(2): 430-4.

64. Gajic O, Dara SI, Mendez JL, et al. Ventilator-associated lung injury in patients without acute lung injury at the onset of mechanical ventilation. Critical care medicine. 2004; 32(9): 1817-24.

65. Wolthuis EK, Veelo DP, Choi G, et al. Mechanical ventilation with lower tidal volumes does not influence the prescription of opioids or sedatives. Critical care. 2007; 11(4): 77.

66. Yilmaz M, Keegan MT, Iscimen R, et al. Toward the prevention of acute lung injury: protocol-guided limitation of large tidal volume ventilation and inappropriate transfusion. Critical care medicine. 2007; 35(7): 1660-6.

67. Determann RM, Royakkers A, Wolthuis EK, et al. Ventilation with lower tidal volumes as compared with conventional tidal volumes for patients without acute lung injury: a preventive randomized controlled trial. Critical care. 2010; 14(1):1.

68. Pinheiro de Oliveira R, Hetzel MP, dos Anjos Silva M, Dallegrave D, Friedman G. Mechanical ventilation with high tidal volume induces inflammation in patients without lung disease. Critical care. 2010; 14(2):39.

69. Khuri SF, Henderson WG, DePalma RG, et al. Determinants of long-term survival after major surgery and the adverse effect of postoperative complications. Annals of surgery. 2005; 242(3): 326-41.

70. Determann RM, Wolthuis EK, Choi G, et al. Lung epithelial injury markers are not influenced by use of lower tidal volumes during elective surgery in patients without preexisting lung injury. American journal of physiology Lung cellular and molecular physiology. 2008; 294(2): 344-50.

71. Treschan TA, Kaisers W, Schaefer MS, et al. Ventilation with low tidal volumes during upper abdominal surgery does not improve postoperative lung function. British journal of anaesthesia. 2012; 109(2): 263-71.

72. Koner O, Celebi S, Balci H, Cetin G, Karaoglu K, Cakar $\mathrm{N}$. Effects of protective and conventional mechanical ventilation on pulmonary function and systemic cytokine release after cardiopulmonary bypass. Intensive care medicine. 2004; 30(4): 620-6.

73. Wrigge H, Uhlig U, Baumgarten G, et al. Mechanical ventilation strategies and inflammatory responses to cardiac surgery: a prospective randomized clinical trial. Intensive care medicine. 2005; 31(10): 1379-87.

74. Zupancich E, Paparella D, Turani F, et al. Mechanical ventilation affects inflammatory mediators in patients undergoing cardiopulmonary bypass for cardiac surgery: a randomized clinical trial. The Journal of thoracic and cardiovascular surgery. 2005; 130(2): 378-83.

75. Sundar S, Novack V, Jervis K, et al. Influence of low tidal volume ventilation on time to extubation in cardiac surgical patients. Anesthesiology. 2011; 114(5): 1102-10. 
76. Serpa Neto A, Cardoso SO, Manetta JA, et al. Association between use of lung-protective ventilation with lower tidal volumes and clinical outcomes among patients without acute respiratory distress syndrome: a meta-analysis. JAMA : the journal of the American Medical Association. 2012; 308(16): 1651-9.

77. Hemmes SN, Serpa Neto A, Schultz MJ. Intraoperative ventilatory strategies to prevent postoperative pulmonary complications: a meta-analysis. Current opinion in anaesthesiology. 2013; 26(2): 126-33.

78. Sutherasan Y, Vargas M, Pelosi P. Protective Mechanical Ventilation in the Non-injured lung: Review and Meta-analysis. Critical care. 2014; 18:N.

79. Amato MB, Barbas CS, Medeiros DM, et al. Effect of a protective-ventilation strategy on mortality in the acute respiratory distress syndrome. The New England journal of medicine. 1998; 338(6): 347-54.

80. Brochard L, Roudot-Thoraval F, Roupie E, et al. Tidal volume reduction for prevention of ventilator-induced lung injury in acute respiratory distress syndrome. The Multicenter Trail Group on Tidal Volume reduction in ARDS. American journal of respiratory and critical care medicine. 1998; 158(6): 1831-8.

81. Brower RG, Shanholtz CB, Fessler HE, et al. Prospective, randomized, controlled clinical trial comparing traditional versus reduced tidal volume ventilation in acute respiratory distress syndrome patients. Critical care medicine. 1999; 27(8): 1492-8.

82. Brower RG, Lanken PN, MacIntyre N, et al. Higher versus lower positive end-expiratory pressures in patients with the acute respiratory distress syndrome. The New England journal of medicine. 2004; 351(4): 327-36.

83. Meade MO, Cook DJ, Guyatt GH, et al. Ventilation strategy using low tidal volumes, recruitment maneuvers, and high positive end-expiratory pressure for acute lung injury and acute respiratory distress syndrome: a randomized controlled trial. JAMA : the journal of the American Medical Association. 2008; 299(6): 637-45.

84. Mercat A, Richard JC, Vielle B, et al. Positive end-expiratory pressure setting in adults with acute lung injury and acute respiratory distress syndrome: a randomized controlled trial. JAMA: the journal of the American Medical Association. 2008; 299(6): 646-55.

85. Guerin C, Reignier J, Richard JC, et al. Prone positioning in severe acute respiratory distress syndrome. The New England journal of medicine. 2013; 368(23): 2159-68.

\section{Correspondence to/Autor za korespondenciju}

Paolo Pelosi, Professor, M.D.

Email address: ppelosi@hotmail.com
86. Beitler JR, Shaefi S, Montesi SB, et al. Prone positioning reduces mortality from acute respiratory distress syndrome in the low tidal volume era: a meta-analysis. Intensive care medicine. 2014; 40(3): 332-41.

87. Lee JM, Bae W, Lee YJ, Cho YJ. The Efficacy and Safety of Prone Positional Ventilation in Acute Respiratory Distress Syndrome: Updated Study-Level Meta-Analysis of 11 Randomized Controlled Trials. Critical care medicine. 2013; 35(3): 288-93.

88. Mikkelsen ME, Shah CV, Meyer NJ, et al. The epidemiology of acute respiratory distress syndrome in patients presenting to the emergency department with severe sepsis. Shock. 2013; 40(5): 375-81.

89. Gajic O, Dabbagh O, Park PK, et al. Early identification of patients at risk of acute lung injury: evaluation of lung injury prediction score in a multicenter cohort study. American journal of respiratory and critical care medicine. 2011; 183(4): 462-70.

90. Setzer F, Oschatz K, Hueter L, Schmidt B, Schwarzkopf $\mathrm{K}$, Schreiber T. Susceptibility to ventilator induced lung injury is increased in senescent rats. Critical care. 2013; 17(3): 99.

91. Janz DR, Zhao Z, Koyama T, et al. Longer storage duration of red blood cells is associated with an increased risk of acute lung injury in patients with sepsis. Annals of intensive care. $2013 ; 3(1): 33$.

92. Arozullah AM, Daley J, Henderson WG, Khuri SF. Multifactorial risk index for predicting postoperative respiratory failure in men after major noncardiac surgery. The National Veterans Administration Surgical Quality Improvement Program. Annals of surgery. 2000; 232(2): 242-53.

93. Arozullah AM, Khuri SF, Henderson WG, Daley J, Participants in the National Veterans Affairs Surgical Quality Improvement $P$. Development and validation of a multifactorial risk index for predicting postoperative pneumonia after major noncardiac surgery. Annals of internal medicine. 2001; 135(10): 847-57.

94. Canet J, Hardman J, Sabate S, et al. PERISCOPE study: predicting post-operative pulmonary complications in Europe. European journal of anaesthesiology. 2011; 28(6): 459-61.

95. Kor DJ, Warner DO, Alsara A, et al. Derivation and diagnostic accuracy of the surgical lung injury prediction model. Anesthesiology. 2011; 115(1): 117-28.

96. Brueckmann B, Villa-Uribe JL, Bateman BT, et al. Development and validation of a score for prediction of postoperative respiratory complications. Anesthesiology. 2013; 118(6): 1276-85. 